\title{
Dangers and Potentialities of the Highly Mobile World: An Ethical Consideration ${ }^{1}$
}

\section{Ilman Choe \\ Myungsim Yang}

\begin{abstract}
Although the field of mobility research has always been interdisciplinary, its relation to philosophy has not been particularly close. This essay attempts to give a philosophical contribution to the field: an ethical consideration regarding mobility. Specifically, the dangers and potentialities in the highly mobile world will be identified and clarified through the phenomenological concepts of lifeworld, home world, and alien world. Our home world will be revealed as the sole foundation of values and norms for us. Based on these concepts, the meaning of mobility and highly mobile world will be clarified, and we will understand how high mobility leads to destabilization of the home world thereby posing a threat to our ethical foundation. Finally, three ethical potentialities that emerge from the highly mobile world will be discussed: new ways of understanding, building of a more universal lifeworld, and formation of a new ethical category.
\end{abstract}

Keywords: mobility, lifeworld, home world, alien world

\section{Introduction}

$\mathrm{M}$

obility is neither a physical movement nor a biological one. Rather, it is a sociological movement, and the original locus of mobility is, thus, human society. The mobility paradigm, stimulated by the increase of sociological movement, tries to understand society on the basis of movement rather than anything else. As such, mobility can be approached by various disciplines which are concerned with human society: a human geographer examines how mobility bears on the way in which geographical elements become meaningful to human beings; a sociologist explores how

${ }^{1}$ This work was supported by the Ministry of Education of the Republic of Korea and the National Research Foundation of Korea (NRF-2018S1A6A3A03043497).

(C) 2021 Ilman Choe and Myungsim Yang

https://www.kritike.org/journal/special issue 2021/choe\&yang april2021.pdf

ISSN 1908-7330

(cc) $\mathrm{BY}-\mathrm{NC}-\mathrm{ND}$ 


\section{DANGERS AND POTENTIALITIES}

mobility is related to various social phenomena; an ethnologist studies the relation of mobility to various cultural groups and communities; a political scientist analyzes how mobility affects the production and distribution of power. Such varying perspectives imply that mobility theories have an interdisciplinary character.

The relation of philosophy to mobility theories is generally not so close, perhaps this is primarily because mobility theories are more concerned with the science of facts, while philosophy is more concerned with the science of essences. ${ }^{2}$ At the same time, however, we know how significant the science of essences is for the science of facts. We should confront the problems of the essences when we trace the fundamental meanings of the concepts used by the science of facts, since the former lays and clarifies the foundations for the latter's fundamental concepts. In the case of mobility theories, an ontology of mobility can help theories secure a solid grounding. It is one of the possible contributions of philosophy to mobility theories. ${ }^{3}$

There is another, unexplored field in which philosophy can contribute to mobility theories: ethics. This field has been relatively neglected. The negligence is understandable, given the suspicion surrounding the science of ethics since the $20^{\text {th }}$ century. In the first half of the century, logical positivism tried to banish all logically or scientifically unverifiable propositions. Since the latter half of the century, the field of ethics has been dominated by metaethics, which deals with ethical language rather than ethical virtues, values, and norms.

It is a sheer impossibility, however, to exclude ethics from the humanities, as morality constitutes one of the most specific and universal features of human beings. Specific, because we do not know of any nonhuman beings with a moral system; universal, because we do not know of any human community that has no moral system at all. We can reassure of ethical matters in mobility theories, especially in politics, because modes of power distribution cannot be separated from the question of the rightness of a specific mode. Modes of power distribution have consequence: one mode is desirable or right, and another is undesirable or wrong. Mobility, then, as a human phenomenon should imply morality.

This essay is an attempt to consider the relation between mobility and ethics. The subject of this attempt is not one of individual mobilities, but that

\footnotetext{
2 These terms are borrowed from Husserl. A science of facts (Tatsachenwissenschaft) is concerned with the concrete factual phenomena, and a science of essences (Wesenswissenschaft) with the abstract, the essential, the universal. Edmund Husserl, Ideas Pertaining to a Pure Phenomenology and to a Phenomenological Philosophy, First Book: General Introduction to a Pure Phenomenology, trans. by Fred Kersten (The Hague: Martinus Nijhoff, 1983), 7-17.

${ }^{3}$ See in particular Thomas Nail, Being and Motion (New York: Oxford University Press, 2019).
}

(c) 2021 Ilman Choe and Myungsim Yang https://www.kritike.org/journal/special issue 2021/choe\&yang april2021.pdf ISSN 1908-7330

(c) $)$ BY-NC-ND 
of a more general one: the highly mobile world of our contemporary time. The central question is: "What ethical values can a highly mobile world have?" As Anita Perkins analyzes in her dissertation, the contemporary hypermobile society has produced the loss of the home, contrary to the positive prospects of being mobile. ${ }^{4}$ In other words, our highly mobile world produces some ethical issues. Such a situation compels us to undertake the task of thinking about the ethics of mobility.

To carry out the task, the concept of the lifeworld, and especially the distinction between the home world and the alien world as proposed by Husserl, the founder of phenomenology, will be discussed. Before we understand what lifeworld is and how it helps accomplish this essay's task, let us first understand the reason on which the concept of the lifeworld is capitalized in this essay. First, it is suitable specifically for understanding human society because it incorporates the layers of values and norms. Second, the distinction between the home world and the alien world is suitable for reflections on mobility as sociological movements.

Before closing this introduction, some terminological and conceptual remarks must be made. Ethics has multiple meanings. On the one hand, it is about happiness and the values of the good and the bad. On the other hand, it is about moral rules and obligation and prohibition. As it is concerned with behaviors when dealing with human beings, it is also concerned with actions in general. These meanings do not adequately coincide, and as such an ethical matter in one meaning can be morally indifferent in the other. The words themselves - ethics and morality - are not well-defined. This difficult matter will not be discussed in this short essay. The intention is to keep the meaning of ethics vague and use the words ethical and moral interchangeably. Thus, ethical or moral matters pertains to one of the above-mentioned meanings.

The structure of this essay is as follows. The concept of the lifeworld and the distinction between the home world and the alien world will be clarified in the second section. Subsequently, the concept of mobility and the values implied by it will be discussed in the third section. This will lead us to the exposition of the ethical dangers of mobility. The fourth section will show that the highly mobile world motivates important ethical actions and considerations, thereby carrying out the task of thinking about the general ethics of mobility. Finally, the fifth section, after a brief summary of the discussion, will present the three ethical potentialities that emerge from the highly mobile world: new ways of understanding, building of a more universal lifeworld, and formation of a new ethical category.

${ }^{4}$ Such a diagnosis makes her question the moral value of being mobile. She asks, "are the new mobilities good for us?" Anita Jean Perkins, "Travel Texts and Moving Cultures: A German-Focused Comparative Analysis in the Context of the Mobilities Turn" (PhD Thesis: University of Otago, New Zealand, 2013), 33, <http://hdl.handle.net/10523/4311>.

(c) 2021 Ilman Choe and Myungsim Yang https://www.kritike.org/journal/special issue 2021/choe\&yang april2021.pdf ISSN 1908-7330 
74 DANGERS AND POTENTIALITIES

\section{Lifeworld, Home World, and Alien World}

\section{Lifeworld}

The concept of a lifeworld, introduced into the philosophical vocabulary by Husserl in Crisis, ${ }^{5}$ has become an important resource for thinking about human life. One reason for this is because, as a lifeworld, it opposes an atomistic way of thinking. It shows that a person not only deals with individual things, but also deals with the encompassing situation. Another reason is because, as a lifeworld, it opposes the positivist way of thinking. It shows that the world in which we live incorporates not only the scientifically verifiable things, but also layers of meanings, values, and norms. As such, it helps us to understand mobility as a sociological movement. For these reasons, the concept of the lifeworld is utilized.

Two guidelines are to be followed here. First, the features of the lifeworld that are relevant to the points of this essay will be discussed. Given the limited space, this essay can by no means fully handle the enormous volume of discussions surrounding the lifeworld. However, three points to keep in mind: 1) the lifeworld is the foundation of human practices; 2) the lifeworld is not a private, but a communal world. 3) the lifeworld, in which a person has originally lived, has a privileged status as their home world, contrary to alien worlds. These points will be discussed later.

The second guideline shall proceed from the simple to the complex. As a concrete world, a lifeworld has complexity; that is, it has various layers on various perspectives: 1) layer of doxa, layer of values, and layer of norms; ${ }^{6}$ 2) personal layer and communal layer; 3 ) epistemological layer and practical layer.

Let us begin with cognition on the personal doxic layer. Let us say we see or remember a house over there. What Husserl pays attention to is that such a perception or a remembrance cannot be related exclusively to the house, or to the visible side of the house in question. Cognition of the house requires a certain kind of awareness of the background needed for a house being recognized as a house. ${ }^{7}$ For example, in order to recognize something

\footnotetext{
${ }^{5}$ See Edmund Husserl, The Crisis of European Sciences and Transcendental Phenomenology: An Introduction to Phenomenological Philosophy, trans. by David Carr (Evanston: Northwestern University Press, 1984).

${ }^{6}$ This trifold distinction is borrowed from Husserl. Doxa is connected to experience, value to desire, norm to will. In his usage, doxa means bare facts stripped of values and norms. Because of a lack of an adequate English word, the term doxa is left untranslated.

7 Consciousness can be used either in the wide sense or in the narrow sense. Consciousness in the narrow sense is contrasted with unconsciousness. Something is consciously in mind of a person when it affects her cognition and action and the fact that it is in her mind is also in her mind. On the contrary, consciousness in the wide sense is being in mind itself, so that

(c) 2021 Ilman Choe and Myungsim Yang https://www.kritike.org/journal/special issue 2021/choe\&yang april2021.pdf ISSN 1908-7330

(c) BY-NC-ND
} 
in the visual field as the foreside of a house, we must be aware of the other sides of the house; otherwise, it cannot be a foreside. In order to envisage a house, we must also be aware of the surroundings of the house. This can be a forest, a city district, or even an indeterminate empty space, but no matter how indeterminate it may be, it must nonetheless be a certain space. In other words, no matter how much we try to envisage a house in non-space, we can only envisage a house in an empty space. Such surroundings, of which we must be aware even if we are not focused on them, are horizons as Husserl calls them. ${ }^{8}$

A horizon is not independent, rather, it also includes its surroundings as its horizons. Also, awareness of a surrounding space implies awareness of further spaces. Aside from spatial horizons, there are also temporal horizons. In order to be aware of a point in time, we must be aware of the preceding point and the following point. When we continue to trace horizons of horizons, we finally get to the ultimate horizon of all the horizons, that is, the world. ${ }^{9}$

The world is the totality of things. It is not, however, a disordered accumulation of things. Things are orderly interconnected in the world. An individual thing can appear only upon the background of an orderly interrelation of things. A foreside of a house is what it is only when its sides are systematically interconnected and is systematically interconnected to its surroundings like trees, cars, and human beings. For this reason, when we see but a foreside of a house, we recognize it as something that also has a backside and stands on the certain ground. In short, the world is the totality of orderly interconnected things.

We can now climb up the stairs of concreteness by a step and bring the action into account. We can then see that the horizons for cognition are also horizons for action. Just from our awareness of the backside of a house, when we see the foreside, we can think about moving ourselves to see the backside. We are also aware of the fact that we will see the backside when we move to the back of the house, because we are aware of orderly relations persisting between our actions and our perceptions. The order of the world guides our action. Thus, the world is a practical world.

As implied in the term "awareness," we are not always explicitly seeing the world as the background of cognition and action. In most cases, we are implicitly aware of the world, that is, in a way that we do not know that

it encompasses both unconsciousness and consciousness in the narrow sense. In order to avoid possible confusion, the word awareness is used for consciousness in the wide sense.

8 See Husserl, Ideas Pertaining to a Pure Phenomenology, 51-55; Edmund Husserl, Analyses Concerning Passive and Active Synthesis: Lectures on Transcendental Logic, trans. by Anthony Steinbock (Dordrecht: Kluwer Academic Publishers, 2001), 44-46.

${ }^{9}$ See Husserl, Ideas Pertaining to a Pure Phenomenology, 51-55.

(c) 2021 Ilman Choe and Myungsim Yang https://www.kritike.org/journal/special issue 2021/choe\&yang april2021.pdf

ISSN 1908-7330 


\section{DANGERS AND POTENTIALITIES}

we are aware of it. We do not explicitly think, "That house must definitely have a backside," when we are looking at its foreside. Nevertheless, we can say that we are aware of it because we naturally move to its back in order to see its backside, or we are not surprised when we accidently see its backside. In this way, our cognitions and actions in relation to the world are, in many cases, done implicitly.

We know the orderly connections of the world not a priori, but a posteriori; that is, because we have learned them by experience and teaching. We are also implicitly aware of them because we have not only learned them but have also embraced them into our habits. When we learn something for the first time, it is strange to us. We cannot take it into account when we do not explicitly keep it in our mind. After we have familiarized ourselves with it through repetition, we can handle it without explicitly thinking about it; it becomes our habit to know how to deal with it. Husserl called such a process habituation. ${ }^{10}$

We should now restore the layers of values and norms. A house not only has doxic aspects, but also various aspects of values and norms. Not only is a house big or small, red or blue, but it is also comfortable or uncomfortable, beautiful or ugly. That is to say, it has values. Our actions are governed not only by doxa, but also by values. We can be motivated by values; for example, we may leave a house or remodel it because we find it uncomfortable. Further, many actions concerning the house is normatively governed. We should not enter others' houses without permission. Not only the things but also the connections of things have aspects of values and norms. The fact that a table is in a house has not only physical meanings but also cultural meanings: the table is there according to our eating conventions.

Layers of values of norms are also habituated. We do not enter others' houses not because we explicitly think about the prohibition. We simply do not enter them. We are not even aware that we are following a rule. Values and norms are habituated in us and this regulates our cognitions and actions.

The world which has all the layers of doxa, values, norms, all the layers of cognitions and actions, and the fully concrete world is the lifeworld. It is the lifeworld because our lives take place in it. In our lives, a house is always a place with cleanliness or dirtiness, comfort or discomfort, and not just a plain space comprised of sizes and volumes. We meet a house as a plain space only when we abstract it from life. Furthermore, objective characteristics themselves gain meanings of values and norms in a lifeworld. For example, the size of a house can be related to the convenience or comfort of the house. Therefore, when we are moving from the physical world to the

10 See Edmund Husserl, Die Lebenswelt: Auslegungen der vorgegebenen Welt und ihrer Konstitution. Texte aus dem Nachlass (1916-1937), ed. by Rochus Sowa (Dordrecht: Springer, 2008), 401.

(c) 2021 Ilman Choe and Myungsim Yang https://www.kritike.org/journal/special issue 2021/choe\&yang april2021.pdf ISSN 1908-7330

(c) $)$ BY-NC-ND 
lifeworld, it is not that things of values and norms are added to the oncephysical world, but that the once-physical things themselves become valuethings and norm-things.

As such, lifeworld includes more than tangible things. Many things with values and norms are intangible like conventions, rules, and laws. Since the term "thing" is easily associated with tangibility, the term "meaningful formation" (Sinngebilde) must be used in order to indicate lifeworldly entities. The term implies that it is formed as something meaningful by us. ${ }^{11}$ Now we can say that lifeworld is a totality of tangible and intangible meaningful formations which behave as the background for all the cognitions and actions regarding doxa, values, and norms.

A lifeworld functions as the grounds for our actions. It gives us reasons for action through habits, meaning-giving, and stability. First, we act simply according to the habits acquired in the lifeworld. We act so because it is the only possible action that we are accustomed to. Second, a lifeworld is the ultimate ground which our rationality can refer to. We do not always act habitually; we ponder upon the reasons for our actions when needed. In this case, we can confront things critically with values and norms in a lifeworld. However, such reflections must be, on their part, grounded in a lifeworld because values and norms can have concrete meanings in reference to meaningful formations in the lifeworld. For example, the rule "do not enter into others' houses without permission" can have meaning only when we know who counts as other, what counts as house, what counts as permission, and so on, and we should refer to the lifeworld in order to know these things. Third, we can rely on a lifeworld because it has abiding stability. When norms of yesterday, today, and tomorrow differ from each other, we will not be able to guide our actions through norms. Since we believe that our lifeworld will last for quite a while, we can rely on norms in this lifeworld.

\section{Lifeworld as a Communal World}

The description of a lifeworld so far has not explicitly taken account of others, only implicitly. This was necessary because meaningful formations in a lifeworld are made by others, received from others, and shared with others. I describe a certain physical thing which I am looking at as a house. Yet, the network of meanings to which a house belongs is not made by myself, but has pre-existed; instead, I have learned from others that that house is a building in which human beings live, that certain actions are permitted and

${ }^{11}$ Literally, Sinn means sense or meaning, and Gebilde means something constructed, built, or formed. Husserl describes things as something formed because it is "constituted" as it is by our consciousness. This essay will not go deeper into his idealism or constitutionism but simply remark that the idea of constitution does not mean that the mind makes things out of nothing.

(c) 2021 Ilman Choe and Myungsim Yang

https://www.kritike.org/journal/special issue 2021/choe\&yang april2021.pdf

ISSN 1908-7330 


\section{DANGERS AND POTENTIALITIES}

others are prohibited in relation to the house. Others are implied in the meaningful formations.

Take note of others, not another. First, the lifeworldly meaningful formations in general are historically and jointly made by many people. Second, even if a meaningful formation can be produced by one person, for it to be constantly valid, a succession of people is needed. Someone must learn it and transfer it to others. While a physical thing can persist without any intervention of human beings, a value or a norm cannot. Third, a meaningful formation can be effective only when a group of people make it effective, that is, when people in a community talk about such a formation, act in accordance with it, and impose penalties for behavior not in accordance with it. Therefore, a lifeworld is a communal world, which presupposes the community of human beings, and relies upon it.

In the opposite direction, a community relies on a shared lifeworld. In order to live together, the same values and the same norms (at least in essential points) are needed. A person who regards a house as a space for all the village people and a person who regards a house as his private sphere cannot get along. Thus, a community can be formed when members share the same idea about the house, as well as the values and norms directing houserelated actions. Accordingly, a community and a lifeworld belong to each other. Each family, town, nation, and state have its own lifeworld.

The mutual belonging of a lifeworld and a community implies above all the finiteness of a lifeworld. Finiteness here means a limitedness of the range of effectiveness of lifeworldly meaningful formations. The idea that a house is one's private space is effective only in a community that accepts it as effective. Outside the community, such an idea does not exist or have validity. The second implication of their mutual belonging is the plurality of lifeworlds, as each community has its own lifeworld.

The finiteness and the plurality of lifeworlds does not imply, however, a clear demarcation between lifeworlds. Just as communities can be included in other communities and overlap with one another, and just as there can be in-between regions of communities, lifeworlds can be so as well. The finiteness and the plurality of lifeworlds does not also imply that the different lifeworlds should have completely different pools of meaningful formations. A certain meaningful formation can belong to many lifeworlds as something more universal, like, say, parents, while another meaningful formation belongs to just one lifeworld as something more community specific. And again, a meaningful formation which is shared by many lifeworlds can have different connection of meanings in different lifeworlds. For example, while all the lifeworlds would have the meaningful formation "parents," ideas about how we should treat them, or even whom we should regard as parents, can be diverse.

(c) 2021 Ilman Choe and Myungsim Yang https://www.kritike.org/journal/special issue 2021/choe\&yang april2021.pdf ISSN 1908-7330

(c) $)$ BY-NC-ND 


\section{Home World and Alien World}

The discussion on the plurality of the lifeworld was still abstract because the fact that $I$ always already live in certain specific lifeworlds has not yet been brought into account. This fact implies that the various lifeworlds are significant to me in different ways. There are lifeworlds, into which I have been born or in which I have lived, whose meaningful formations I have learned. Learning and habituation began before I gained self-consciousness and continued after I became self-conscious.

Such lifeworlds are special to me as I take them for granted and act accordingly without being conscious of my actions. As such, my lifeworlds constitute a world that is familiar to me. This familiarity means, first of all, that I can behave skillfully and effortlessly in these lifeworlds, while my actions become clumsy in others. In such unfamiliar lifeworlds, I do not know how to regulate my actions. This familiarity has, on the other hand, emotional effects. In those lifeworlds, I may feel at home, while I become anxious in other lifeworlds. Those lifeworlds, within which we feel familiarity, are called home worlds by Husserl. Other lifeworlds, which lie beyond our home world and unsettle us, are called alien worlds. ${ }^{12}$

\section{Mobility and Its Ethical Dangers}

In the previous section, we have gained conceptual tools of the lifeworld and the home/alien world, with which we can now examine ethically problematic situations brought about by increased mobility. Let us begin by attempting to clarify the notion of mobility, after which we will then discuss the significance of a highly mobile world, and finally conclude by showing its ethical dangers.

\section{Notion of Mobility}

The notion of mobility is vague and heterogeneous. On the one hand, mobility refers to the movement of people: travel, commute, immigration, studying abroad, and so on. However, mobility also suggests movements of things like distribution, import, and export. Further, mobility can extend to movements of information through telephone, media, the Internet, and smartphones. All these definitions involve locomotion, but they are not the sole subject of mobility theories. Mobility theories focus also on the corporeal mobility of human beings such as in dance or sports. In order to examine the

${ }^{12}$ For a fuller exposition on the problematic of home world and alien world, see Anthony J. Steinbock, Home and Beyond: Generative Phenomenology after Husserl (Evanston, IL: Northwestern University Press, 1995).

(c) 2021 Ilman Choe and Myungsim Yang https://www.kritike.org/journal/special issue 2021/choe\&yang april2021.pdf ISSN 1908-7330 


\section{DANGERS AND POTENTIALITIES}

ethical consequences of mobility, we should more or less acquire a clear notion of mobility.

Clarifying the notion of mobility is not about securing a clear-cut definition. Mobility is not a single concept, but a name for a problematic that grows and complicates itself throughout history. In this case, an unambiguous definition cannot be given because new related phenomena can always be discovered, widening the coverage of the notion of mobility. As such, the notion of mobility is inherently equivocal. Dealing with such a notion, it is better to try and find the core of the meaning, which enables the process of historical complexifications.

A good starting point to find the core would be to look at the beginning of the problematic. We had begun to pay attention to the problems of mobility in the latter half of the $20^{\text {th }}$ century, motivated by the fact that the world was moving much more than before. The question is, which movements did we have in mind when we were saying that the world was moving? Of course, it was not the rotation of the Earth or other such natural phenomena. It referred to the global movement of travelers and trade goods.

First, they were locomotion on a global scale, that is, the movements of people and goods across the borders of states and continents.

Second, they were movements with lifeworldly meanings. Not all forms of locomotion-for example, the movement of clouds-are regarded as mobility. The difference between the movement of clouds and that of people and goods does not lie in the fact that the former is a physical movement, because the latter also has a physical aspect. The difference lies in that the latter is more than a physical movement. Travel is not simply a locomotion of people, but also something fun, rewarding, or tiring. Trading is not simply a relocation of things, but also something that increases convenience or pleasure in human society. Movements that are categorized as mobility are, say, movements with lifeworldly meanings. ${ }^{13}$

However, not all the movements with lifeworldly meanings count as mobility. This is because, as already mentioned, lifeworldly meanings are also imposed on physical things in a lifeworld. The movement of clouds also has values - it changes the weather and affects our feelings of delight and melancholy, although it does not count as a mobility Thus, it seems that mobility should be understood as movement produced by human activity. Not only do people and goods move, they are also intentionally moved by us.

Now we can describe the core of mobility as a change of location with lifeworldly meanings that are brought about by human activity. Such movements are the ones that saw a massive increase in the latter half of the $20^{\text {th }}$ century

${ }^{13}$ In the same vein, Cresswell describes mobility as movement with meaning. See Tim Cresswell, On the Move. Mobility in the Modern Western World (New York: Routledge, 2006), 2-4.

(c) 2021 Ilman Choe and Myungsim Yang

https://www.kritike.org/journal/special issue 2021/choe\&yang april2021.pdf

ISSN 1908-7330

(c) $)$ BY-NC-ND 
and that motivated sociologists and other scholars to try and understand the world on the basis of mobility. They were the starting point of the mobility paradigm and mobility theories.

The range of the problematic of mobility has since grown from the core meaning. Movement of information is not the movement of physical things, but it can be called mobility because it has lifeworldly meanings, is produced by human activity, and is in a sense also a change of location. Bodily motions are not a change of location, but can be called mobility because they have lifeworldly meanings, are produced by human activity, and are what enables other mobilities. Even further, we must speculate on the ontology of motion if we are to understand what enables all the mobilities on a fundamental level. The core meaning of mobility is not called the core in the sense that it determines the range of mobility theories, but because it gave and gives rise to it.

\section{Lifeworldly Meanings of the Highly Mobile World}

Now that we have grasped the core meaning of mobility, we can move on to examine how modes of mobility have transformed in the contemporary world in order to describe their meanings and ethical consequences.

What was invented is the notion of mobility, not the reality of mobility. Mobilities, even long-distance mobilities, have existed from long ago. Our ancestors migrated from Africa to other parts of the world, marched across continents, and sailed across seas. But such ventures were rare events that only a few people willfully or forcibly dared to undertake. Mobilities in the past were also much slower than they are now. Long-distance travel required several months, even years. In both aspects, it is now vastly different: mobilities in the contemporary world are much more frequent and faster-the world is now highly mobile.

Mobilization of the world, given impetus by technological and political innovations, has had huge effects on lifeworlds. First, the increase in frequency led to the changes of our valuations concerning sedentarism and nomadism. Although the words sedentary and nomadic are primarily descriptive, they also acquire normative valuations within the lifeworld. In ancient Greece, for example, nomadic life was undesirable, and movement was tolerated only when it was a way back home, that is, a return to a sedentary life. ${ }^{14}$ A life with a stable home and family was desirable and valuable, while nomadic life was gazed upon in a suspicious or even contemptuous manner. Such a system of value began to change as more

\footnotetext{
${ }^{14}$ Perkins analyzes the Odyssean journey to show such valuations regarding sedentarism and nomadism in ancient Greece. See Perkins, "Travel Texts and Moving Cultures," 34ff.

(c) 2021 Ilman Choe and Myungsim Yang https://www.kritike.org/journal/special issue 2021/choe\&yang april2021.pdf ISSN 1908-7330 


\section{DANGERS AND POTENTIALITIES}

possibilities of mobility were gradually popularized with faster ships, horse carriages, and so on. With new mobilities vast areas of new experiences were now open-encounters with unknown people and cultures, examination of different lifestyles, consciousness of a wider world not confined to national borders, etc. Such experiences were regarded as contributing to selfeducation, and thus, positive values were granted to the mobile life. ${ }^{15}$ This new system of value continues in the contemporary world, demonstrated by, for example, an increasing public interest in the nomadic lifestyle. ${ }^{16}$

Second, the increase of speed has contracted the world. Now we can cover in a day distances that people in the past needed several months or years to traverse. This shrinks the space in reality-states, continents have never been so close. ${ }^{17}$ On the lifeworldly perspective, the contraction of space implies that there are more frequent encounters with alien worlds. In addition, the further we travel, the more we will probably encounter alien worlds that contrast heavily with our home world. In the past, the mobilities of a majority of people were confined in their own provinces or nations. Now it is not difficult to cross borders of states or even continents. There we may meet alien worlds that have almost nothing in common with our home world.

\section{Ethical Dangers of High Mobility}

It is time now to demonstrate how a highly mobile world may give rise to ethical dangers. There are ethical dangers because of the fact that the highly mobile world threatens to unsettle the home world. The home world is the taken-for-granted, sole, lasting lifeworld; and thus, we can rely upon it. The highly mobile world can, however, undermine the stability of home world, that is, of the reliable ground for actions.

The stability of the home world is grounded on a sedentary mode of life because a lifeworld becomes one's home world through habituations which are enabled by repetitions over time. In other words, habituations are possible when members of a community share the same meaningful formations, teach and learn them from one another, and think and act according to them over time. For this to happen, the same members should remain in the same world over a long period of time.

The highly mobile world threatens this condition. First, encounters with alien worlds harms the way we take for granted the home world. This

\footnotetext{
${ }^{15}$ Here, she analyzes a diversity of values attributed to mobilities in modern German literature. Ibid., $49 \mathrm{ff}$.

${ }^{16}$ For further discussions on sedentarism and nomadism, see Peter Adey, Mobility, Second Edition (New York: Routledge, 2017), 69-101.

${ }^{17}$ For a detailed analysis of this phenomenon, see David Harvey, The Condition of Postmodernity. An Enquiry into the Origins of Cultural Change (Cambridge, MA: Blackwell, 1990), $260 \mathrm{ff}$.

(c) 2021 Ilman Choe and Myungsim Yang https://www.kritike.org/journal/special issue 2021/choe\&yang april2021.pdf ISSN 1908-7330

(c) BY-NC-ND
} 
mindset of "taking for granted" is more than the fact that $I$ consciously take for granted my home worlds and the meaningful formations within it. It is not that I have consciously pondered over whether I should take my home world for granted and judged that I should, therefore, it is a prereflective state of mind. For example, when it is taken for granted in my home world that we should go into the house without any shoes on, I do not recognize it as a norm. I simply take off my shoes and go into a house. I realize it as a particular norm for the first time when I encounter a lifeworld in which people enter houses with shoes on, and I can no longer take it for granted. Second, encounters with alien worlds harm the oneness of home world. What this suggests is not the trivial fact that I have only one home world, but that my home world is only one lifeworld that I am aware of, and that I am not even aware of the possibility of other lifeworlds. Through encounters with the alien world, I see the possibility and the reality of other lifeworlds and recognize my home world for the first time as a particular lifeworld among lifeworlds. Now, there is plurality of lifeworlds. In this way, encounters with alien worlds unsettle the home world by damaging its oneness and how we "take it for granted." While it is not particularly difficult to relieve the unsettling effects in a world with low mobility, in a highly mobile world this poses a fairly difficult, if not impossible, task.

First, frequent encounters with alien worlds in the highly mobile world inhibit the habitual operations of home-worldly thinking and action. When our normal habitual thinking and action is performed undisturbed, it reinforces our habits recursively and stables our habitual world. On the contrary, when it is disturbed, for example by unexpected or hostile responses of people from an alien world, it can undermine the respective habitualities. In a world with less mobility, this disturbance is not frequent enough to generally undermine the habitualities; but in a highly mobile world, habitual thinking and action can fail so frequently that a considerable part of habitualities can become unstable.

Second, frequent encounters with alien worlds establishes a need to take alien worlds seriously. In a world with less mobility, we can take alien worlds lightly with few undesirable consequences. In other words, we can regard an alien meaningful formation as an eccentricity, a one-shot event, or a spectacle; that is, it can be regarded as something which does not really belong to our world. Such a temporary measure does not work in a highly mobile world, because encounters with alien meaningful formations already belong to our home world. Therefore, we cannot live an unobstructed life without solving the question of how to deal with alien worlds.

Now we can see why the highly mobile world can destabilize the privileged position of the home world as the ground for cognition and action. In the previous paragraph, it was said that a home world can hold such a

(c) 2021 Ilman Choe and Myungsim Yang https://www.kritike.org/journal/special issue 2021/choe\&yang april2021.pdf ISSN 1908-7330 


\section{DANGERS AND POTENTIALITIES}

position because 1) we act according to habitualities in our home world, 2) we refer to our home world to make sense of values and norms, 3) our home world has persisted for a long time and is thus reliable. In the highly mobile world 1) our habitual action is frequently disturbed, 2) there are other meaningful formations to which we can refer, 3) frequent exchange with alien worlds can change meaningful formations of our home world, rendering the home world unstable.

The result is that we cannot confidently perform actions personally as well as mutually because our home world, our personal and communal ground for action, is undermined or can be even lost. Destabilization of our home world also carries emotional consequences, like depression and anxiety. ${ }^{18}$ This is the ethical danger implied in a highly mobile world. In this way, our highly mobile world presents to us not only economic, cultural, and political challenges, but also ethical challenges.

\section{Ethical Potentialities of the Highly Mobile World}

In the previous section, we have seen how an ethically problematic situation is created in the highly mobile world. But we are not completely overwhelmed by such problems in the contemporary, highly mobile world. We try to cope with them, and such attempts also open the gate to new ethical potentialities: 1) new ways of understanding; 2 ) building of a more universal lifeworld; 3) formation of a new ethical category.

An unstable home world unsettles the ground for action. To solve this problem, it seems that the home world should be restabilized. Yet, it cannot be restored to the old home world, because such a restoration implies the exclusion of alien worlds. This would be undesirable as well as impossible in the new conditions of the highly mobile world. The restabilization that is needed is the establishment of a new, more universal lifeworld encompassing the old home world and the respective alien world. Before describing such a making of a home world, we must discuss the essential premise for it: understanding. Alien worlds should be understood in order to be integrated.

\section{Understanding}

There are two kinds of understanding: an intelligent one and an emotional one. An intelligent understanding is the cognition of the reason

${ }^{18}$ It is not that the home world collapses necessarily and completely, leaving its members entirely helpless. Such a disintegration is an extreme case, although not impossible. Such destabilizing effects are implied in the nature of the highly mobile world, but they can become actualized to various degrees. Their actualizations can range from a small quarrel with a foreigner aroused by different conceptions of politeness to the absence of social consensus with regards to the right attitude to multicultural families.

(c) 2021 Ilman Choe and Myungsim Yang https://www.kritike.org/journal/special issue 2021/choe\&yang april2021.pdf

ISSN 1908-7330

(cc) BY-NC-ND 
and motivational connection of the actions of others. ${ }^{19}$ An emotional understanding is the act of empathizing, that is, feeling what others feel. Only the first kind will be dealt with here, because 1) two kinds of understanding can be performed in separation, 2) another word, "empathy," is ready for the second kind, and 3) what is essential in conversation and cooperation is the first kind.

Again, intelligent understanding has three levels. On the first level, we understand others by acknowledging their motivations that we also share. We can understand why a man cries when his daughter dies because we would also be sad if our daughter dies. On the second level, we understand others by figuring out their motivations, which itself we may not have, but which we can accept coherently in our motivational network. When a woman cries when her dog dies, it is possible that we do not understand her crying because we do not have the motivational connection between crying and our dog's death. However, we can try to figure out her motivation by recognizing that we will cry when our family member dies, and that we can accept even an animal as a family member if we live together with it and love it. On the third level, we understand others by somehow figuring out their motivations despite not sharing them and accepting them within our own network of motivations. For example, when a man loves another man or a woman loves another woman, it is possible that we do not understand him or her not only because we do not have that particular motivation of love, but also because we believe that homosexuality is against the nature of human beings. For an understanding to happen in this case, we can utilize epoché, in Husserl's sense. Epoché is an operation where the validity of meaningful formations is suspended, neither believing nor rejecting the formation, thereby making them ineffective to our cognitions and actions. Through epoché, we can suspend our beliefs and try to see the world as the others see it, learn their perspective, and finally understand them. ${ }^{20}$

The understanding on the third level proposes a conundrum, which can lead us to an abandonment of understanding. We can file such actions in the category of the absurd and describe them as being incomprehensible to us, or even inherently incomprehensible, as homophobic people would do in

${ }^{19}$ In the theory of action in the analytic tradition, an action is explained in terms of rationality, that is, the faculty to give reasons for action. But it can restrict the range of human actions because a large part of our action is performed not by reason, but by feelings, instincts, habitualities, and so on. The term motivation, which is common in the phenomenological tradition, can be a more appropriate tool for explaining a wider range of human actions.

${ }^{20}$ See Husserl, Ideas Pertaining to a Pure Phenomenology, 57-62. Husserl first proposed epoché in the context of epistemological reflection but examines later also the possibility and significance of the ethical epoché. See also Edmund Husserl, Erste Philosophie (1923/24), Zweiter Teil: Theorie der phänomenologischen Reduktion, ed. by Rudolf Boehm (The Hague: Martinus Nijhoff, 1959), 319.

(c) 2021 Ilman Choe and Myungsim Yang https://www.kritike.org/journal/special issue 2021/choe\&yang april2021.pdf ISSN 1908-7330 


\section{DANGERS AND POTENTIALITIES}

our example. The abandonment of understanding need not imply hostility because we can also simply tolerate the incomprehensible without understanding. However, such a tolerance presupposes distancing because, firstly, the lack of understanding can make serious conversation and cooperation impossible and, secondly, unavoidable encounters with incomprehensible actions within an intimate relationship may become irritating sooner or later. Living together intimately requires understanding.

Understanding is already an ethical action because it is an effort to treat a person as a person. Motivation is a characteristic feature of person. A thing can only be known, not understood, because there is no motivation in its behavior and thus nothing to be understood. It is possible to ignore and neglect the motivations of a person, but this would mean that we take this person as a thing rather than a person. When we try to understand them, we give justice to their personhood, that is, we begin to act ethically. Understanding on the third level is even more ethical, because on the first and second level we do not grasp the person's singularity, since we see their motivations as reflections of our own motivation. On the third level, however, we try to grasp motivations which lie beyond our network of motivations. In other words, we try to take the other as the other, not as a mirror image of ourselves.

What have been discussed hitherto in the personal sphere can be applied to the intersubjective or social sphere. A motivation has social existence when it is shared and justified by members of a community. Something is socially known when knowledge about it is shared and talked about between members of a community. Accordingly, we can say that motivations of a community are understood by another community when the motivations have social existence in the former and the knowledge about it has a social existence in the latter.

We have seen that the abandonment of understanding is undesirable in an intimate relationship in the personal sphere. The equivalent situation of an intimate relationship in the social sphere is brought about by the highly mobile world. In a world with little mobility, a community can hardly be in a close relationship with another community. In this case, it is not too troublesome to abandon understanding of another community because there is little interaction between them. On the contrary, the highly mobile world implies constant interaction and cooperation between communities, and therefore, demands understanding of other communities. In our example, when a community in which homosexuality is taboo engages in frequent exchanges with another community in which homosexuality is socially accepted, a need for understanding is brought about. This demand for understanding is the first ethical potentiality of the highly mobile world.

(c) 2021 Ilman Choe and Myungsim Yang

https://www.kritike.org/journal/special issue 2021/choe\&yang april2021.pdf

ISSN 1908-7330

(c) $)$ BY-NC-ND 


\section{Building of a More Universal Lifeworld}

As mentioned above, understanding is not the destination. In our original life in the home world, we have only one perspective. We acquire other perspectives by understanding alien worlds. However, we are still left with conflicting perspectives and the question of how to act reasonably is unanswered. In order to answer this question, we need a coherent world.

We strive to banish contradictions from our lifeworld and make it coherent. It is not only an intelligent desire to establish a coherent system of knowledge, but also a practical desire; that is, it is a desire to be able to act reasonably. First, we cannot justify our acts without a coherent lifeworld. In that case, a reason may be right in one perspective, and another reason may be right in another; we cannot argue for a particular perspective because we do not have a common ground to perform a practical estimation of diverse perspectives. We are then left with no choice but to choose one perspective arbitrarily. Second, we cannot establish a coherence of an action over time. Many actions happen in different stretches of time. A certain action can take minutes, hours, or even years. In that case, the unity of an action in time is guaranteed by abiding reasons for it. With the plurality of conflicting perspectives, however, reasons are prone to change, so that the unity of action is spoiled.

Therefore, we need to restore a coherent lifeworld. As mentioned above, such a restoration demands the establishment of a new home world rather than a recovery of the old one or its takeover by alien worlds. The newly established home world will be a synthesis of the old home and alien worlds.

As there are three kinds of understanding, we can identify three ways of synthesis. First, some meaningful formations from an alien world can have analogous counterparts in our home world. In this case, they can be easily assimilated into our home world. Second, it is possible that some alien meaningful formations do not have similar counterparts in our home world while also not conflicting with our other meaningful formations; such formations can be coherently placed within our home world. In both cases, the synthesis of two worlds does not pose particularly difficult problems. Synthesis becomes a real problem when some alien meaningful formations conflict with meaningful formations in our home world-such a situation is always possible, because there is no pre-established harmony between the home world and alien worlds. Finally, conflicts should be resolved. Such a resolution is possible only when we descend to a more fundamental level. We need to, say, step back from the conflicting meaningful formations and to find a common background to them. Here we can utilize epoché again: by suspending the superficial effects of meaningful formations, we can bring their background to light.

(c) 2021 Ilman Choe and Myungsim Yang

https://www.kritike.org/journal/special issue 2021/choe\&yang april2021.pdf

ISSN 1908-7330

(cc) BY-NC-ND 


\section{DANGERS AND POTENTIALITIES}

An important question concerning epoché is how universal it should be. Husserl's first attempt at epoché, inspired by Descartes' doubt, aimed for a fully universal suspension of meaningful formations. He strived to arrive thereby at ultimate principles, from which he would rebuild the system of meaningful formations. Such an attempt has difficulties. First, in the course of speculation, we must use meaningful formations in the world: we must have knowledge about what the mind is; what thinking, perception, feeling is; about the language we use; and so on. Second, even if it is possible to suspend all the meaningful formations except the principles, they would be too empty or formal to rebuild into a concrete system. Realizing the problems of his earlier attempts, Husserl later developed ways of epoché that retain more or less concreteness, a deeper discussion of which is outside the scope of this paper. ${ }^{21}$ What is important for us here is that the epoché which we need for the synthesis of lifeworlds is also not absolutely universal, because concreteness matters much more in the practical sphere.

We need not, and should not, try to find a universal ground for all possible worlds. We merely need to take the number of steps necessary to arrive at the meaningful formations shared and agreed upon by two lifeworlds. Grounded on those meaningful formations, we can deal with the conflicting elements of both worlds concretely and critically. Such critical considerations can yield various results: discarding certain meaningful formations, compromising between conflicting meaningful formations, or inventing a new network of meaningful formations. In either of these ways, we acquire a revised lifeworld, with modified networks of meaningful formations. In our example, we can suspend different beliefs and opinions about homosexuality, and try to find a common ground in concepts of, for example, the human being, love, and marriage. We can reflect upon and discuss the matter of homosexuality on this shared ground, finding agreeable new meaningful formations. We would introduce these new meaningful formations into our original home worlds, respectively, which could require discarding some conflicting previous meaningful formations. Now we are ready to integrate two worlds. This is how the third way of synthesis can come about.

It is indeed possible that the original home world should lose some meaningful formations (e.g., the belief in the heterosexual nature of human beings) through some process of revision. In extreme cases, the newly synthesized world can appear as a radically different world from the original home world. Nonetheless, it is not a replacement, but a synthesis, because the revision is based on the common ground between the home world and the

${ }^{21}$ For clarification of the various ways of epoché, see Iso Kern, "The Three Ways to the Transcendental Reduction," in Husserl: Expositions and Appraisals, ed. by Frederick A. Elliston and Peter McCormick (Notre Dame, IN: University of Notre Dame Press, 1977).

(c) 2021 Ilman Choe and Myungsim Yang

https://www.kritike.org/journal/special issue 2021/choe\&yang april2021.pdf

ISSN 1908-7330

(c) $)$ BY-NC-ND 
alien world. Also, although some meaningful formations on the surface of the resulting lifeworld can be quite different, the newly synthesized world cannot be radically different from the original home world in the strictest sense, because they share the same radix (root).

The revised lifeworld does have a kind of universality, but not an absolute universality in the sense of Kant or Hegel. Not Kantian, because it is not formal. He tried to arrive at universality by abstracting from concreteness and leaping to the most universal laws, which are indeed universal, but empty, due to their formality. The world we get here is a world with all the concrete meaningful formations. Not Hegelian, because the universality of the revised lifeworld is not conceptually predestined and derived. The synthesis here is accomplished through actual actions and interactions, such as critical reflection and assessment, conversation and discussion; the result cannot be foreseen. The revised lifeworld is nonetheless a more universal one, relative to the former ones, in the sense that it provides a coherent and stable ground for members of the original home world and the original alien world alike. Ethical universality can be achieved in this way, that is, gradually and progressively through syntheses of lifeworlds. The opportunity for such a universalization is bestowed through encounters with the alien world. It is the second ethical potentiality implied in the highly mobile world.

\section{A New Ethical Category}

Thus, a more universal lifeworld can be gained by understanding and synthesizing. Now we have a novel lifeworld, which will function as the ground for our practices. The resulting lifeworld is, at first, not a proper home world, however. Although its fundamental grounds are left unmodified, and its many meaningful formations are untouched by the revision, it is possible that members no longer feel "at home" because of unfamiliar meaningful formations, e.g., new rules or changed valuations. The becoming-homeworld of the revised lifeworld can happen only through collective habitualization, which requires time.

Not only habitualization requires time, but also the understanding and synthesizing that comes before it. First, all the courses of thinking-understanding, epoché, critical estimation, and synthesizing-is time-consuming. Understanding a single alien meaningful formation is already not a simple task, because it also requires an understanding of connections in which that meaningful formation is involved. Each phase of mental work required to carry out a synthesis-epoché, critical reflection and assessment, figuring out new desirable meaningful formations, etc.-is also time-consuming. Moreover, all the thoughts must be socially digested; that is, a shared conception must be established through mutual exchange and

(c) 2021 Ilman Choe and Myungsim Yang

https://www.kritike.org/journal/special issue 2021/choe\&yang april2021.pdf

ISSN 1908-7330

(cc) BY-NC-ND 


\section{DANGERS AND POTENTIALITIES}

discussion of relevant thoughts. The result is that we must live through a certain period where we experience a reduced at-homeness.

The problem is compounded when we remember that the success of synthesizing lifeworlds is not guaranteed. As stated above, ethics demands universality de jure, but this does not mean an effective universal ethical system is always de facto possible. This is because the effectiveness of an ethical system relies on its concreteness. For example, take the universal rule of "thou shall not lie." One and the other can accept it, and so it appears that they have established a universal ground. At the same time, however, the idea of what counts as a lie is different for each other according to their respective lifeworldly network of meaningful formations. Then, in effect, they follow different or maybe conflicting rules. Conversation and discussion between people from different lifeworlds do not guarantee that they will agree on the same concrete ethical system. The possibility of an effective universalization cannot be predicted, and unresolvable conflicts are possible.

In the highly mobile world, therefore, we cannot help but live in a home world destabilized or unsettled by encounters with alien worlds over an undetermined period of time. It would therefore be important for us to learn not only how to restore the home world, but also how to live in an unsettling home world, or, more fruitfully, how to live with a plurality of lifeworlds. Even if we do not have a stable ground for action, we do not want to be caught in a state where we are anxious and unable to act. On the one hand, and as far as possible, we want to act reasonably, based on the grounds which we can consult in the here and now, but on the other hand, we do not want to neglect the alien world altogether. We therefore need other guidelines for action than the ones that could be employed within a stable home world. Virtues like tolerance, negotiation, or compromise would be required-virtues which were largely neglected in universality-oriented ethics. For example, when there is a universal division between right and wrong, negotiation would not be a virtue, but rather an expedient, if not a wrongdoing, because something absolutely right should not be negotiated. But, if the rightness of an action is judged on the basis of the lifeworld, where there is a plurality of lifeworlds, where the unification of lifeworlds is not guaranteed, and when we experience conflicts between lifeworlds-in short, if we live among frequent encounters with alien worlds due to high mobility - negotiation can be a requisite. Such virtues can be called virtues or ethical norms because they regulate or enable actions to interact with other human beings as human beings. They form an ethical category, which is seldom discussed in traditional ethical theories.

This section leaves a closer examination of this new category for future studies will close with some remarks on norms concerning the home world which may belong to this category. It seems that we should change our

(c) 2021 Ilman Choe and Myungsim Yang

https://www.kritike.org/journal/special issue 2021/choe\&yang april2021.pdf

ISSN 1908-7330

(c) $)$ BY-NC-ND 
way of understanding the home world in a highly mobile world. The conception of the home world as the lifeworld and the ground for action is based on sedentary conditions of the past, which may have been changed forever. In our time of high mobility, the home world may not be a static, closed, unchanged world. It may be open to frequent encounters with the alien world and may include values and norms concerning interactions with alien worlds. In this way, the highly mobile world calls for a new ethical category, a new conception of the home world. It is another ethical potentiality of the highly mobile world. ${ }^{22}$

\section{Closing Remarks}

We have seen the ethical dangers and potentialities of the highly mobile world. The dangers speak of how our home world may be destabilized by frequent encounters with the alien world, so that we may lose our ground for action and fall into anxiety over the inability to act. Potentialities refer to how an understanding of the other is socially demanded, that a gradual universalization of ethical systems is stimulated, and that a new ethical category is called for living in the unsettling home world and frequently encountering the alien world. Anita Perkins's question "are the new mobilities good for us?" cannot be answered with a yes or a no, but with an examination of the dangers and the potentialities implied in a highly mobile world. This essay is one such possible attempt. Other dangers and potentialities may be discovered through further attempts focusing on other aspects of mobility.

This essay closes with a remark on a point that was not taken into account for the sake of keeping the discussion relatively simple. This point is that a home world can already be a place of discomfort and anxiety for some of its members because certain norms in the home world can be repressive to them. The fact that it remains their home world-because it is habituated in them and is the only world they can refer to-makes the situation more difficult as there is no escape for these members. To them, encounters with the alien world can be an experience of liberation, because the home world loses its privilege as the lifeworld, and other ways of life are opened. It can thus stimulate them to seek, or to make a lifeworld in which they can lead a

\footnotetext{
${ }^{22}$ In this context, we can see so-called nomadism not only as a distinctive descriptive mode of life, but also as an ethical way of life. For further discussions on nomadism, see Adey, Mobility, $81 \mathrm{ff}$.
}

(c) 2021 Ilman Choe and Myungsim Yang https://www.kritike.org/journal/special issue 2021/choe\&yang april2021.pdf ISSN 1908-7330 


\section{DANGERS AND POTENTIALITIES}

free, happy life. Here we can see another ethical potentiality of the highly mobile world.

Institute of Philosophy, University of Würzburg, Germany The Academy of Mobility Humanities, Konkuk University, South Korea

\section{References}

Adey, Peter, Mobility, Second Edition (New York: Routledge, 2017).

Cresswell, Tim, On the Move: Mobility in the Modern Western World (New York: Routledge, 2006).

Harvey, David, The Condition of Postmodernity: An Enquiry into the Origins of Cultural Change (Cambridge, MA: Blackwell, 1990).

Husserl, Edmund, Erste Philosophie (1923/24), Zweiter Teil: Theorie der phänomenologischen Reduktion, ed. by Rudolf Boehm (The Hague: Martinus Nijhoff, 1959). Ideas Pertaining to a Pure Phenomenology and to a Phenomenological Philosophy, First Book: General Introduction to a Pure Phenomenology, trans. by Fred Kersten (The Hague: Martinus Nijhoff, 1983). The Crisis of European Sciences and Transcendental Phenomenology: An Introduction to Phenomenological Philosophy, trans. by David Carr (Evanston: Northwestern University Press, 1984). Analyses Concerning Passive and Active Synthesis: Lectures on Transcendental Logic, trans. by Anthony Steinbock (Dordrecht: Kluwer Academic Publishers, 2001).

Die Lebenswelt: Auslegungen der vorgegebenen Welt und ihrer Konstitution. Texte aus dem Nachlass (1916-1937), ed. by Rochus Sowa (Dordrecht: Springer, 2008).

Kern, Iso, "The Three Ways to the Transcendental Reduction," in Husserl: Expositions and Appraisals, ed. by Frederick A. Elliston and Peter McCormick (Notre Dame, IN: University of Notre Dame Press, 1977). Nail, Thomas, Being and Motion (New York: Oxford University Press, 2019).

Perkins, Anita Jean, "Travel Texts and Moving Cultures: A German-Focused Comparative Analysis in the Context of the Mobilities Turn" (PhD Thesis: University of Otago, New Zealand, 2013), http://hdl.handle.net/10523/4311.

Steinbock, Anthony J., Home and Beyond: Generative Phenomenology after Husserl (Evanston: Northwestern University Press, 1995).

(c) 2021 Ilman Choe and Myungsim Yang https://www.kritike.org/journal/special issue 2021/choe\&yang april2021.pdf ISSN 1908-7330 